\title{
DEVELOPING LANGUAGE SKILLS IN PRE-SCHOOL CHILDREN WITH SPECIAL EDUCATIONAL NEEDS IN THE COURSE OF INCLUSIVE EDUCATION
}

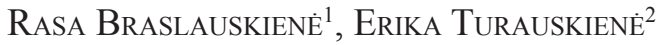 \\ Klaipėda University (Lithuania)
}

\begin{abstract}
This article analyses the opinion of pre-school teachers on the peculiarities of the development of language skills of pre-school children with special educational needs in inclusive education. The conclusions of the qualitative research highlight the opinion of educators that in the course of inclusive education in kindergarten, the oral and written language skills of children with special needs require development during their daily activities. It turns out that in order to develop children's speaking and listening skills, educators develop children's fine motor skills, initiate language games, read fairy tales, encourage an interest in folklore, initiate dialogue reading, etc. In order to develop the basics of children's reading and writing, educators involve children with special educational needs in various creative activities, organise various games, allow children to act using information and communication technologies, etc.

KEY WORDS: special educational needs, language skills, inclusive education.
\end{abstract}

JEL CODES: I21, I25

DOI: http://dx.doi.org/10.15181/rfds.v34i2.2242

\section{Introduction}

Today's education and training discourses emphasise that every child is a unique, proactive, changing individual that must be given an opportunity to grow and be educated where his or her needs and educational support needs are best met (Kauffman, Anastasion, Badar et al., 2016; Babinskienè, 2021). As a result, children with special educational needs (hereinafter SENs) have recently been included in groups of children with normal development.

The logic of research allows us to state that it is important to develop children's oral and written language skills in pre-school, as good personal language skills are the basis for successful education and quality of life (Bražienė, Šalkuvienė, 2020; Žičkevičienė, Bagdonas, 2020). Jakavonytė-Staškuvienė (2018) notes that one of the most advanced ways to develop language skills is inclusive education. The importance of educational inclusion is emphasised in documents: the 'Law Amending the Law on Education of the Republic of Lithuania' (2011), and the 'Lithuanian Progress Strategy "Lithuania 2030" (2012), which state that an intelligent society must recognise the rights of socially excluded people to help them be full members of the society and actively participate in social inclusion activities. The 'National Strategy for Education 2013-2022' (2014)

1 Rasa Braslauskienè - Professor, Doctor of Social Sciences, Klaipeda University, Faculty of Social Sciences and Humanities Scientific interests: teacher training, special pedagogy, pre-school and primary education, social and family policy

E-mail: rasa.braslauskiene@gmail.com

Tel. +370 46398631

2 Erika Turauskienè - Assistant, Klaipèda University, Faculty of Social Sciences and Humanities

Scientific interests: development of teacher competences, pre-school and primary education, inclusive education

E-mail: bagdonaviciute.erika@gmail.com

Tel. +37065367361 
and Unesco (2016) update the importance of access to education and equal opportunities in the implementation of inclusive education.

Both foreign and Lithuanian researchers have written and analysed the peculiarities of language skills development. Yustina (2012), Beinorienė, Gražienė (2016), Jankauskienė, Rinkevičiūtè (2017), Hutton, Phelan, Horowitz-Kraus, et al. (2017), Jakavonytė-Staškuvienè (2018), and Brodin, Renblad (2018) et al. analysed how to help children develop speaking and listening skills. Teixidor (2014), Jakavonytė-Staškuvienė, Vozbinaitė (2016), Monkevičienè (2018), Locher, Fost (2019), Celik (2020), Bražienė, Šalkuvienè (2020) and others have researched how to develop children's reading and writing skills. Bos, Braeckel, Hitzert (2013), Jūrevičiūtė (2013), Suggate, Pufke, Stoeger (2016), Zachovajevas, Katkienė, Šegždaitè et al. (2018), and Bunce (2020) et al. highlighted the peculiarities of fine motor skills training. Baravykaitè-Dagiené, Getkienė, Burvytė et al. (2014), Savickytė (2018), and Žičkevičienė, Bagdonas (2020) revealed the significance of fairy tales to the development of children's language skills. Augustiniené, Burinskienè, Kajokienè (2013), and Braslauskienè, Norviliené, Šmitienè et al. (2018) examined the possibilities of media and information communication technologies in developing children's language skills. Turauskienè (2019), and Turauskienè, Braslauskienè (2020) wrote about the possibilities of pedagogues' cooperation with parents in developing children's communication competence.

The peculiarities of children's oral and written language education are discussed in works by foreign and Lithuanian researchers. However, there is a lack of research papers analysing the development of the language skills of pre-school children with special educational needs in the course of inclusive education. Therefore, this article raises the problem question: what are the peculiarities of language development of pre-school children with SEN in inclusive education?

The object of the research is the opinion of pre-school education teachers about the peculiarities of the development of language skills of pre-school children with special educational needs in the course of inclusive education.

The aim of the research: to reveal the peculiarities of the development of language skills of pre-school age children with special educational needs through inclusive education.

Research methods: theoretical (analysis of scientific literature and documents); empirical (partially structured interviews, content analysis).

1. Theoretical definition of the development of language skills of pre-school children with special educational needs in inclusive education

The ability to communicate with a variety of people, to speak, to listen actively, to read, to write, is important in the daily life of a 21 st-century child. Children with good oral and written language skills gain opportunities to express themselves successfully, communicate, summarise information, solve problems, and learn (Beinorienè, Gražienė, 2016; Žičkevičienė, Bagdonas, 2020). Therefore, pre-school teachers (hereinafter PSTs) providing inclusive education should pay special attention to the development of children's spoken and written language. The description of pre-school children's achievements (2014) state that:

- Spoken language is the child's listening and speaking. When listening, the child gets used to listening, recognising the differences in the sounds of speech and frequently pronounced combinations of sounds. By speaking, the child learns to speak, to express her opinion, and share her experience in spoken language. The most important attention points in the development of children's spoken language are: children's speech should not be pushed into any formal framework; the norms of language communicated to children must not be detrimental to their individual linguistic expression; children are encouraged to speak dialect and literary language; children's linguistic expression is combined with image, movement, and facial expressions; works of folklore and fiction are read to children; spoken and written children's language is to be developed at the same time.

- Written language is writing and reading. Writing begins with the first lines, strokes, randomly written letter elements, and copied letters. Reading to a child means understanding the meaning of symbols, 
recognising the first short words and letters and associating them with sounds. The success of learning to read is determined by the child's ability to actively listen and speak. The most important emphases in the development of children's written language include: to look for opportunities for the expression of children's written language every day; to awaken children's desire to produce rhinestones, drawings, and letters on a daily basis; to keep talking to children about what they have drawn and written, about the stories they read; to link illustrations viewed to children's experiences, and more.

The development of language skills in a pre-school education group is an integral part of the life of the group. Each children's day at an educational institution consists of situations which naturally develop the children's language skills. Children, irrespective of their gender, functional abilities, or social or cultural background, can communicate naturally by playing, during their breakfast, lunch, afternoon snacks, etc, on a daily basis (Schady, 2011; Hille, Evanschitzhy, Bauer, 2015). But along with natural situations training children's linguistic abilities, other educational methods are applied, as well as means that PSTs choose, taking into consideration their learners' individual experience, capacities, and development patterns.

In improving children's oral language skills, PSTs: talk to children about their words and sounds; initiate linguistic games, children-children, and children-adult conversations; read various literary works to children; help learners learn poetry by heart; encourage activities with information and communication technology (hereinafter ICT); and ask children to listen to audio records and to discuss them, etc (Razgevičiené, 2016; Jankauskienė, Rinkevičiūtė, 2017; Savickytė, 2018; Turauskienė, Braslauskienė, 2020; Žičkevičienė, Bagdonas, 2020). In educating the children's written skills, PSTs: initiate games, creative activities, encourage to act by using ICT, ask children to copy letters, analyse literary works of different genres, etc (Teixidor, 2014; Hille at al., 2015; Jakavonytė-Staškuvienė, Vozbinaite, 2016; Braslauskienė et al., 2018; Monkevičienė, 2018). In developing children's fine motor skills PSTs: ask children to fasten and unfasten buttons, to collect pebbles of various sizes, put beans, peas, grains into boxes, to string beads, to fold napkins; encourage children to mould, cut, construct, colour, etc (Jurevičiūtè, 2013; Burškaitienė, 2018; Bunce, 2020). The most popular methods for language development include reading and discussing literature, encouraging playing didactic games, and initiation of creative activities. The most popular innovative methods for language development include activities with ICT, encouraging and initiating innovative games (the game 'Letter Yoga', tasks using a bee-robot), and involving the learners in various projects (Turauskiene, Braslauskienè, 2020).

Žičkevičienè, Bagdonas (2020) note that, in educating children's linguistic skills, PSTs face the following difficulties: children's speech is not well articulated, they stutter, behave aggressively, and are not willing to communicate and collaborate. In trying to solve these issues, in the course of inclusive education, PSTs should collaborate with their learners' parents, colleagues (speech therapists, special educators, social workers, psychologists), to be partners in play for children, to create a good atmosphere, to encourage children to communicate with children with special needs, to reinforce children's trust in each other, etc.

\section{Research methodology}

To reveal PSTs' opinions of aspects of developing linguistic skills in pre-school children with SEN in the course of inclusive education, the qualitative research method was chosen. In the research, information, data and the results of research provided in academic literature and documents was collected, analysed and systematised; a research strategy was chosen, the research design was created; a research instrument was created; a partially structured interview was conducted; the data were analysed and summarised, and a research report was prepared. The substantiation of the qualitative research was based on the interpretation paradigm (Cohen, Manion, Morrison, 2007) and the constructivist approach (Berger, Luckamann, 1999). They were applied in order to provide an interpretation, a comprehensive view of the situation analysed, the experience lived of the persons involved in it, and an explanation arising from an analysis of the situation.

Research participants. According to Bitinas (2013), in carrying out qualitative research, the selection of research participants depends on the research aim. According to Gaižauskaite, Valavičienè (2016), in car- 
rying out an interview, the creation of a sample may be formed at the data collection stage. But the primary creation of the view of research participants should be logical and well considered. The sample units from the general set in this research were selected by a non-probability sampling. Taking into consideration the aim of the research, individuals were selected for the research that may give meaningful information about the research object. In this case, that is five PSTs working in a group of inclusive education. These teachers have work experience with children with emotional, behavioural and developmental problems, and attention and activity delays. An inclusive group is understood in this study as one that recognises the right of every child to be educated with peers. The demographic characteristics of the research participants are presented in Table 1.

Table 1. Demographic characteristics of informants

\begin{tabular}{|l|l|l|}
\hline \multicolumn{1}{|c|}{ Code } & \multicolumn{1}{c|}{ Length of teaching service } & \multicolumn{1}{c|}{ Qualification category } \\
\hline P1 & $4 \mathrm{yrs}$ & Teacher \\
\hline P2 & $7 \mathrm{yrs}$ & Senior teacher \\
\hline P3 & $5 \mathrm{yrs}$ & Senior teacher \\
\hline P4 & $11 \mathrm{yrs}$ & Methodologist \\
\hline P5 & $34 \mathrm{yrs}$ & Methodologist \\
\hline
\end{tabular}

Source: the authors, 2021.

The data in Table 1 show that one PST, two senior PST, and two PST teachers-supervisors took part in the research. The teaching service of the informants ranges from four to 34 years. Such a sample is sufficient, since, by applying the individual interview method, the recommended sample size is from five to 30 persons (Brinkman, 2018).

The research was conducted in March 2021. An interview method was chosen for the research. One of the advantages of the interview method is that the research participants may submit their answers to the questions by using their terms, and they are allowed to express their opinion, which helps to reveal the essence of the object researched. In the case of this research, the chosen data collection method was partially structured interviews. By conducting partially structured interviews, it was planned to ask the foreseen questions, but not to 'stick' to them: their places could easily be interchanged, and additional questions were asked (Rupšiene, 2007; Karvelienè, 2019). The choice of partially structured interviews was determined by the flexibility of the method, immediacy, and the possibility to ask additional questions.

During the interview, the key blocs of interview questions included: demographic data (what is the length of your teaching service? What is your qualification category?); the questions intended for finding out PSTs, opinion about the peculiarities of developing linguistic skills in pre-school children with SEN in the course of inclusive education (How do you understand the statement 'developing linguistic skills in the course of inclusive education'? What problems do you face in developing linguistic skills in children with SEN in inclusive education? Why is it useful to develop the linguistic skills in children with SEN by including SEN children in a group of children with normal development? What methods, means and tools do you use in the implementation of the development of the written/oral language of SEN children in the course of inclusive education?); the questions intended for emphasising PSTs' opinions of future prospects in the development of SEN pre-school children's linguistic skills in the course of inclusive education (How do you propose to improve the development of the linguistic skills of SEN children in the course of the implementation of inclusive education in the future?).

Research instrument. According to Rupšienè (2007), the research instrument in qualitative research is the researcher himself/herself. Bitinas (2013) calls the researcher a cognition instrument which directly interacts with the subjects in fulfilling the function of scientific cognition instrument, she tries to understand, to experience the nature and essence of educational phenomena. It is presumed that the objectivity of the 
educational research is partial, the personal experience and emphatic insights are an integral part of the data received, but the research instrument tries to stay neutral with regard to the research results, she tries to remove the effect of her personality on the interpretation of the result analysis.

Data analysis. The data received in the course of the interview was transcribed and analysed. According to teachers-supervisors (Creswell, 2013; Gaižauskaitè, Valavičienè et al., 2016), a formula to analyse the text interview material is non-existent. Hence, the key principle of this research data analysis was defined: the content of the text was analysed in a consistent manner, by dividing the content analysed into codes, subcategories, and categories. 'Singling out the analytical units in the qualitative research analysis should be understood not as a structured process but rather the art of interpretation, hence singling out codes, subcategories and categories is a process of creative thinking, by aiming at decoding the meanings underlying in the text' (Karveliene, 2019: 60). Each informant in this research was granted a random code (P1, P2, P3, P4, P5). Having written all the text, the interview transcripts were coded. After coding the text, a division of extracts from the text of the interview was carried out. Each coded reply from an informant was transferred to a table by writing the code next to it. After transferring the coded text into the table, data grouping was performed. The coded interview data already presented in the table were grouped into groups and subgroups according to certain features. On the division of the data received during the interview into groups and subgroups, a detailed data description was performed. On the basis of the data collected by the informants, a qualitative content analysis was performed. This method enables us to single out the experience, values and interests of the informants.

Research validity, reliability. To ensure the validity of the research, it was attempted to create an environment based on mutual trust between the informants and the researcher: informants were told that the informants are coded (research data are confidential), and clear questions were formulated. Hesse-Biber, Leavy (2011), Bitinas (2013) and Žydžiūnaite, Sabaliauskas (2017) note that the limitations of the qualitative research should be associated with the subjectivity that is inevitable in qualitative research. Hence, even though the requirements necessary for this kind of research were complied with in the course of planning and carrying out the qualitative research, the generalisation of the research results was limited by the small number of research participants. Namely, the qualitative research results are unique, and characteristic only of the people participating in the actual research.

Research ethics. In the course of the research, the principles of confidentiality, the voluntary nature and anonymity were complied with.

\section{Results}

In the course of the research, it was attempted to find out how PSTs understand the statement 'developing of linguistic skills in the course of inclusive education'. The research results revealed that: 'development of linguistic expressions (...) is intended for children whose development is advanced, normal or delayed' (P1); 'development, taking into consideration the (...) child's competences, abilities, possibilities, temper, character and needs, aiming at (...) making the required sounds, to reinforce the functioning of the organs of speech and to encourage to acquire oral language that would be understandable to all' (P2); 'language development, its enrichment, cognition (...) in the group, where there are (...) children that have difficulties in mastering language and experiencing various difficulties' (P3); 'development of active talking and listening by a child, the formation of the basics of reading and writing, taking into consideration the needs of each child' (P4); 'that is personalised development of oral and written language in line with the needs of each child and capacities' (P5). Summarising the data, we can see that the development of language skills in the course of inclusive education is the development of speaking, listening, writing and reading competences taking into consideration the capacities of each child, her needs, temper and character.

The PSTs that participated in the research were asked to single out which oral language development methods, means, tools they use in the course of inclusive education of SEN children. The research results are presented in Table 2. 
Table 2. Methods, means and tools of development of oral language skills

\begin{tabular}{|c|c|c|c|}
\hline Category & Subcategory & Illustrating statements & $\begin{array}{l}\text { Number of } \\
\text { repetitive } \\
\text { statements }\end{array}$ \\
\hline \multirow{13}{*}{$\begin{array}{l}\text { Methods, } \\
\text { means and tools } \\
\text { of development } \\
\text { of oral } \\
\text { language skills }\end{array}$} & Repetition of sounds & We repeat (...) sounds $(\mathrm{P} 4 ; \mathrm{P} 5)$ & 2 \\
\hline & $\begin{array}{l}\text { Learning poems and } \\
\text { songs }\end{array}$ & $\begin{array}{l}\text { we sing songs and demonstrate movements }(\mathrm{P} 2) \\
\text { To memorise poems, lyrics of songs }(\mathrm{P} 5)\end{array}$ & 2 \\
\hline & Practising articulation & we practise articulation $(\mathrm{P} 4)$ & 1 \\
\hline & Games & We play (...) games $(\mathrm{P} 2, \mathrm{P} 3, \mathrm{P} 4, \mathrm{P} 5)$ & 4 \\
\hline & Reading literature & $\begin{array}{l}\text { To listen to the texts read (...) to feel the mood of the } \\
\text { piece of writing }(\mathrm{P} 2, \mathrm{P} 4, \mathrm{P} 5)\end{array}$ & 3 \\
\hline & Dialogue reading & $\begin{array}{l}\text { By analysing various texts pieces of writing (...) it is } \\
\text { important to (...) to discuss them (...) to ask children: } \\
\text { 'What did you understand? Why did this happen? Is this } \\
\text { possible in reality?' ( } \mathrm{P} 1, \mathrm{P} 4, \mathrm{P} 5)\end{array}$ & 3 \\
\hline & Conversations & They tell (...) stories (P1, P2, P3, P5) & 4 \\
\hline & Staging & Staging (P3) & 1 \\
\hline & 'Brainstorming' & 'Brainstorming'(P3) & 1 \\
\hline & Creating stories & $\begin{array}{l}\text { to continue stories, to add various details, (...) to change } \\
\text { the course, the end of the story (...) the characters(P5) }\end{array}$ & 1 \\
\hline & Activities with IT & By watching animation, playing an online game (P5) & 1 \\
\hline & $\begin{array}{l}\text { Encouraging curiosity, } \\
\text { researching }\end{array}$ & $\begin{array}{l}\text { I encourage curiosity, ask to research (...) the capacities } \\
\text { of technologies (...) dictionaries, calendars (P5) }\end{array}$ & 1 \\
\hline & $\begin{array}{l}\text { Explanation of linguistic } \\
\text { etiquette }\end{array}$ & I teach not to interrupt the person speaking (P5) & 1 \\
\hline
\end{tabular}

Source: the authors, 2021.

Table 2 illustrates that PSTs, in developing children's oral language skills in the course of inclusive education of SEN children, encourage children to play various games ('Continue if you Can', 'Broken Telephone', 'Author's Chair', etc) (informants P2, P3, P4, P5); initiate conversations (P2, P5 ask children to talk about their free time, hobbies and family; P2 talks with children about what they are doing if they get dressed, 'We put on our jacket, shoes, winter hat', if they wash themselves, 'We turn on the tap, take the soap', if they eat, 'We take a spoon, eat meat') (informants P1, P2, P3, P5); read various literary works to children (informants P2, P4, P5); apply a dialogue reading method (informants $\mathrm{P} 1, \mathrm{P} 4, \mathrm{P} 5)$; encourage the children to repeat the sounds of animals and the environment (informants $\mathrm{P} 4, \mathrm{P} 5)$; sing songs and demonstrate movements, teach to learn poems by heart (informants P2, P5); initiate practising articulation (informants P4); stages (informant P3); uses 'Brainstorming'method (informant P3); encourages children to continue, to add to stories they already know (informant P5); initiates activities with ICT; encourages to research the possibilities of technology, dictionaries, calendars; introduces the rules of linguistic etiquette (informant P5). This is also confirmed by Bražiene, Šalkuvienè (2020), who claim that folk writing, games, plays, counting games, tongue-twisters and imitations are irreplaceable in the development of linguistic hearing in children, expanding the vocabulary and developing language coherence. 'The games have encoded (...) basics of lexis, morphology, syntax, accentuation (...) phonetic expression of words, initial effort to focus attention. By playing, the oral language is expressed in an emotional way in all respects, its laws and composition are consolidated (...). Counting games, tongue-twisters and sound imitations are all linguistic practices for exercising the tongue, and improving linguistic hearing and pronunciation' (Bražienè, Šalkuvienè, 2020: 7). According to Boyd and Bee (2011), the better the child's oral language is developed, the sooner he or she will learn to read and write.

Through the research, we aimed to find out which written language development methods, means and tools PSTs use in the course of inclusive education of SEN children? The research results are presented in Table 3. 
Table 3. Methods, means and tools in the development of written language skills.

\begin{tabular}{|c|c|c|c|}
\hline Category & Subcategory & Illustrating statements & $\begin{array}{l}\text { Number of } \\
\text { repetitive } \\
\text { statements }\end{array}$ \\
\hline \multirow{6}{*}{$\begin{array}{l}\text { Methods, } \\
\text { means and } \\
\text { tools of } \\
\text { development } \\
\text { of written } \\
\text { language } \\
\text { skills }\end{array}$} & Creative activities & we propose to perform creative work $(\mathrm{P} 2, \mathrm{P} 4)$ & 2 \\
\hline & $\begin{array}{l}\text { Copying letters, } \\
\text { writing }\end{array}$ & $\begin{array}{l}\text { show forms of letters }- \text { straight lines and curved (P3) } \\
\text { I allow children to encircle, write and copy letters (P1, P4, P5) }\end{array}$ & 4 \\
\hline & $\begin{array}{l}\text { Developing fine } \\
\text { motor skills }\end{array}$ & $\begin{array}{l}\text { we stimulate fingers, their pads (...) we mold, put buttons, } \\
\text { small objects from one container to another (P2, } \mathrm{P} 4) \\
\text { I improve their fine motor skills, hand to eye coordination skills (P5) }\end{array}$ & 3 \\
\hline & $\begin{array}{l}\text { Method 'A secret } \\
\text { letter' }\end{array}$ & $\begin{array}{l}\text { a child writes a word on a white sheet of paper with a white } \\
\text { crayon, and then colours the entire sheet with chosen colours } \\
\text { of water-colour and a miracle happens - letters emerge (P4) }\end{array}$ & 1 \\
\hline & $\begin{array}{l}\text { Teaching to master } \\
\text { drawing and writing } \\
\text { tools, scissors }\end{array}$ & $\begin{array}{l}\text { I teach how to properly hold scissors, writing instruments, I } \\
\text { ask to cut various figures }(\mathrm{P} 1, \mathrm{P} 3, \mathrm{P} 4)\end{array}$ & 3 \\
\hline & $\begin{array}{l}\text { Giving individual } \\
\text { attention }\end{array}$ & Individual assistance (...) attention $(\mathrm{P} 3)$ & 1 \\
\hline
\end{tabular}

Source: the authors, 2021.

By analysing the data presented in Table 3, it emerged that PST, in developing written language competence in the course of developing the inclusive education of SEN: encourage children to copy, draw letters (informants P1, P3, P4, P5); develop fine motor skills (informants P2, P4, P5); teach children how to correctly hold drawing, writing instruments, scissors (informants $\mathrm{P} 1, \mathrm{P} 3, \mathrm{P} 4)$; initiate creative activities (suggest children paint, draw lines, doodle by using paint brushes, fingers, ear sticks, straws, stamps, etc) (informants P2, P4); applies the method 'A secret letter' (informant P4); give children individual attention by providing the necessary assistance (informant P3). According to Valinskienè (2012), children should first of all be taught to write, and then gradually taught how to read. Acquaintance with writing starts with a letter, the graphic form of which is easiest to memorise by noting the similarity between a letter and an object. Hence, scholars (Valinskiene, 2012; Bražienė, Šalkuviene, 2020) advise teaching letters in a picturesque manner. The shapes of letters may be depicted by children by a movement of a hand in the air, then by a movement with a leg on the ground, or a movement of a finger on their desk. Children may prepare for writing by drawing letters in sand, subsequently writing them on a large sheet of paper. Hence, writing is like a consequent action from drawing. Bražienė and Šalkuvienè (2020) emphasise that by teaching letters, it is important not only to recognise graphic signs, such as certain letters, but also to be able to associate letters with the respective sounds, and to distinguish those sounds in the flow of speech. Hence, it is highly important to develop children's linguistic hearing.

The answers to PST interviews, on which problems they face in the course of the implementation of inclusive education of SEN children, are presented in Table 4.

Having analysed the answers received (Table 4), the difficulties PSTs face most frequently in the implementation of the inclusive education of SEN children may be singled out, which include: SEN children have diffculties focusing (informants $\mathrm{P} 2, \mathrm{P} 4, \mathrm{P} 5)$; are unwilling to talk, repeat words pronounced (informants P1, P2); fail to comply with procedures, agreements and rules of the group (informants P2, P5). During the interview, P2 and P5 noted that the fingers of SEN children are often 'not functioning'. The children are unable to correctly hold scissors or writing instruments, are unable to join dotted pictures, P5 claimed during the interview. The research has shown that, in attempting to help SEN children to overcome their difficulties, PSTs collaborate with the parents of their learners and other specialists (including speech therapists, psychologists, etc).

In the research, it was important to find out why it is useful to develop the language of SEN children by including them with neurotypical children. The research results are presented in Table 5. 
Table 4. Difficulties in the development of language skills in the implementation of inclusive education of SEN children

\begin{tabular}{|c|c|c|c|}
\hline Category & Subcategory & Illustrating statements & $\begin{array}{l}\text { Number of } \\
\text { repetitive } \\
\text { statements }\end{array}$ \\
\hline \multirow{6}{*}{$\begin{array}{l}\text { Difficulties in } \\
\text { the development } \\
\text { of language } \\
\text { skills in the } \\
\text { implementation } \\
\text { of inclusive } \\
\text { education of } \\
\text { SEN children }\end{array}$} & $\begin{array}{l}\text { Unwillingness to } \\
\text { talk, repeat the words } \\
\text { pronounced }\end{array}$ & $\begin{array}{l}\text { children are unwilling to repeat (...) the words } \\
\text { pronounced }(\mathrm{P} 1, \mathrm{P} 2)\end{array}$ & 2 \\
\hline & Failure to focus & failure to focus (P2, $\mathrm{P} 4, \mathrm{P} 5)$ & 3 \\
\hline & $\begin{array}{l}\text { Poorly developed fine } \\
\text { motor skills }\end{array}$ & $\begin{array}{l}\text { their fingers were simply not 'functioning'- they were } \\
\text { stiff, not flexible, hard (P2) } \\
\text { they do not know how to correctly hold scissors, are } \\
\text { unable to join the dotted pictures (P5) }\end{array}$ & 2 \\
\hline & $\begin{array}{l}\text { Failure to comply with } \\
\text { rules, agreements }\end{array}$ & $\begin{array}{l}\text { have difficulties complying with agreements, requests } \\
(\mathrm{P} 2, \mathrm{P} 5)\end{array}$ & 2 \\
\hline & $\begin{array}{l}\text { Poorly developed active } \\
\text { listening skills }\end{array}$ & fail to listen to their friends $(\mathrm{P} 1)$ & 1 \\
\hline & Poor vocabulary & $\begin{array}{l}\text { talk little, the sentences are (...) short (...) poor } \\
\text { vocabulary (P3, P5) }\end{array}$ & 2 \\
\hline
\end{tabular}

Source: the authors, 2021.

Table 5. The benefits of inclusive education

\begin{tabular}{|c|c|c|c|}
\hline Category & Subcategory & Illustrating statements & $\begin{array}{c}\text { Number of } \\
\text { repetitive } \\
\text { statements }\end{array}$ \\
\hline \multirow{4}{*}{$\begin{array}{l}\text { The } \\
\text { benefits of } \\
\text { inclusive } \\
\text { education }\end{array}$} & $\begin{array}{l}\text { Learners that perform better } \\
\text { help others }\end{array}$ & $\begin{array}{l}\text { Communication }(. . .) \text { in the group }(\ldots) \text { enables other } \\
\text { children to attempt to perform better }(\mathrm{P} 1, \mathrm{P} 2, \mathrm{P} 3, \mathrm{P} 4)\end{array}$ & 4 \\
\hline & $\begin{array}{l}\text { Children, PSTs learn to } \\
\text { understand differences }\end{array}$ & We learn to accept differences with respect $(\mathrm{P} 4, \mathrm{P} 5)$ & 2 \\
\hline & $\begin{array}{l}\text { Children, parents, PSTs } \\
\text { develop their problem- } \\
\text { solving skills }\end{array}$ & they help to look for various problem-solving ways $(\mathrm{P} 1)$ & 1 \\
\hline & Equal rights are ensured & $\begin{array}{l}\text { This ensures equal opportunities, and accessibility of } \\
\text { education (P5) }\end{array}$ & 1 \\
\hline
\end{tabular}

Source: the authors, 2021.

According to PSTs (Table 5), inclusive education is useful for all: the SEN children attending the group, and neurotypical children, their parents, and PSTs, since: learners with better performance may help children who are performing worse to improve (informants P1, P2, P3, P4); the children attending the group, and their teachers, learn to communicate, accept 'different' people as they are (informants P4, P5); children, their parents, and teachers leave their comfort zone, improve their problem-solving competences (informants P1); equal rights and opportunities are ensured for everybody (informant P5). Inclusive education is useful for developing the language skills of SEN children. According to Kauffman et al. (2016), inclusive education creates an interactive, child-oriented educational environment. According to Kyriazopoulou, Bartolo, Björck-Åkesson et al. (2017), inclusive education of SEN children creates conditions to reveal the strengths of children; awakens their curiosity; encourages getting involved in problem solving; and develops the competence to communicate with different people. According to Babinskienè (2021), SEN children should be given conditions to be educated in the nearest educational institution together with their peers. 
In the research, it was attempted to find out how PSTs suggest improving the development of language skills of SEN children by implementing inclusive education in the future. The research results are presented in Table 6 .

Table 6. Improving the development of language skills in SEN children through inclusive education

\begin{tabular}{|c|c|c|c|}
\hline Category & Subcategory & Illustrating statements & $\begin{array}{l}\text { Number of } \\
\text { repetitive } \\
\text { statements }\end{array}$ \\
\hline \multirow{16}{*}{$\begin{array}{l}\text { Improvement of } \\
\text { the development } \\
\text { of language } \\
\text { skills in SEN } \\
\text { children in } \\
\text { the course } \\
\text { of inclusive } \\
\text { education }\end{array}$} & $\begin{array}{l}\text { To involve more specialists in } \\
\text { the process of the development } \\
\text { of language competences }\end{array}$ & specialist assistance is needed (P2, P3, P4) & 3 \\
\hline & $\begin{array}{l}\text { To involve children's parents in } \\
\text { the process of the development } \\
\text { of language competences }\end{array}$ & To collaborate with parents $(\mathrm{P} 2, \mathrm{P} 4, \mathrm{P} 5)$ & 3 \\
\hline & $\begin{array}{l}\text { To give more attention to the } \\
\text { individualisation of education }\end{array}$ & $\begin{array}{l}\text { we need to adjust [the content] to them (...) to } \\
\text { offer individualised tasks that encourage (...) } \\
\text { interest, willingness to work }(\mathrm{P} 2, \mathrm{P} 4)\end{array}$ & 2 \\
\hline & To equip relaxation rooms & we need separate rooms (...) for relaxation $(\mathrm{P} 2)$ & 1 \\
\hline & $\begin{array}{l}\text { To reduce the number of } \\
\text { children in groups of inclusive } \\
\text { education }\end{array}$ & $\begin{array}{l}\text { to reduce the number of children in groups }(\mathrm{P} 3 \text {, } \\
\mathrm{P} 4)\end{array}$ & 2 \\
\hline & To improve PST competences & For educators (...) to improve, to learn $(\mathrm{P} 2, \mathrm{P} 4)$ & 2 \\
\hline & To try movement in learning & $\begin{array}{l}\text { To try movement in learning so that children } \\
\text { can change the environment }(\mathrm{P} 4)\end{array}$ & 1 \\
\hline & To use STE(A)M methodology & To try STEM and STEAM methodologies (P4) & 1 \\
\hline & $\begin{array}{l}\text { To take over the good practice } \\
\text { of foreign educators }\end{array}$ & $\begin{array}{l}\text { To take over good practice from other countries, } \\
\text { for instance, Scandinavian countries }(\mathrm{P} 4)\end{array}$ & 1 \\
\hline & $\begin{array}{l}\text { Not to be afraid of making } \\
\text { mistakes, to take risks }\end{array}$ & $\begin{array}{l}\text { Not to be afraid to try out new methods of } \\
\text { education and never to lose hope }(\mathrm{P} 1, \mathrm{P} 4)\end{array}$ & 2 \\
\hline & $\begin{array}{l}\text { To preserve positive education } \\
\text { principles }\end{array}$ & $\begin{array}{l}\text { To preserve positive education principles, to } \\
\text { accept the learner as }(\text { s/he) is, not to condemn } \\
\text { him/her and not to humiliate, even in one's } \\
\text { mind }(\mathrm{P} 4, \mathrm{P} 5)\end{array}$ & 2 \\
\hline & To read more fiction & $\begin{array}{l}\text { To analyse fairy tales more often, to allow } \\
\text { children to listen to them (P1) }\end{array}$ & 1 \\
\hline & To ask children open questions & $\begin{array}{l}\text { To ask children questions, to encourage them to } \\
\text { talk as much as possible, to pronounce as many } \\
\text { sounds as possible ( } 1 \text { 1) }\end{array}$ & 1 \\
\hline & $\begin{array}{l}\text { To enrich the learning } \\
\text { environment }\end{array}$ & $\begin{array}{l}\text { To create (...) a rich, challenging environment } \\
\text { for language learning (P5) }\end{array}$ & 1 \\
\hline & To be a role model for children & $\begin{array}{l}\text { To keep language etiquette themselves (...) to } \\
\text { talk in a calm manner, without rushing (P5) }\end{array}$ & 1 \\
\hline & $\begin{array}{l}\text { To use as many visuals as } \\
\text { possible }\end{array}$ & To use visuals to illustrate stories (P5) & 1 \\
\hline
\end{tabular}

Source: the authors, 2021.

The data in Table 6 show that to improve the development of language skills in SEN children in the course of inclusive education, in the future once should: involve more actively in the process of the development of language skills speech therapists, ergotherapists, psychologists (informants P2, P3, P4), parents (informants P2, P4, P5); PSTs should give more attention to the individualisation of language development (informants P2, P4); to constantly learn, improve the skills of working with SEN children (informants P2, $\mathrm{P} 4)$; to keep to positive education principles (informants $\mathrm{P} 4, \mathrm{P} 5)$; to reduce the number of children in groups 
of inclusive education (informants $\mathrm{P} 3, \mathrm{P} 4)$; to equip relaxations rooms (informant $\mathrm{P} 2$ ); to try out education in movement; to use STE(A)M methodology; to take over the best practice of foreign countries (informant P4); to constantly renew, enrich the learning environment; to use more visuals; for PST to keep linguistic etiquette, to talk in a calm manner, not to rush (informant P5), etc.

The qualitative research emphasises PSTs' opinions of the peculiarities of developing language skills in children with SEN in the course of inclusive education. PSTs implementing the inclusive education of SEN children reveal what educational methods, means and tools they use in developing children's oral and written language; name the problems that pre-school SEN children face; define possibilities for the improvement of the development of language skills in SEN children in the course of inclusive education, etc.

\section{Conclusions}

The qualitative research has revealed that, according to educators, the development of language skills in the course of the implementation of inclusive education in SEN children includes developing speaking, listening, writing and reading skills, by taking into consideration the abilities, needs, temper and character of each child. The interview results emphasise the peculiarities of language development. According to the educators, in the course of inclusive education in kindergartens, the oral and written language skills of children with special educational needs develop naturally during their daily activities. But PSTs implementing the inclusive education of SEN children, in attempting to develop oral language skills, encourage children to play various games; initiate conversations; apply the method of dialogue reading; initiate articulation practice; encourage researching the opportunities offered by information technology; familiarise children with the rules of linguistic etiquette, etc. It emerged that, in developing written language skills in children, PSTs encourage children to copy and write letters; teach them to use correctly drawing, writing instruments, scissors; initiate creative activities; give children individual attention by giving them the necessary assistance, etc.

The research found that educators implementing inclusive education face the following difficulties among SEN children: a lack of focus; an unwillingness to repeat words already pronounced; they are unable to follow the procedures of the group. In order to resolve these difficulties, the informants communicate and collaborate with the parents of their learners. Their close collaboration with the parents helps to establish clear limits for the children; brings parents, children and educators closer; and ensures the continuity and quality of education. According to the educators, to improve the development of language skills of SEN children in the course of inclusive education, in the future, specialists and parents should be involved more proactively, the number of children in groups of inclusive education should be reduced; education in movement should be tried; STE(A)M methodologies should be used; best practices from foreign countries should be adopted, etc.

In summarising the qualitative research findings, it is important to note the research limitations. The limitation of qualitative research is associated with subjectivity, which is inevitable in qualitative research. Even though the necessary requirements for this kind of research were complied with in planning and carrying out the research, the generalisation of the research results and the possibilities to apply them are limited by the rather small number of research participants. Namely, the qualitative research results are unique and characteristic only of the people that participated in the research. The conclusions of the research allow us to state that the research into the development of language skills in pre-school children with SEN in the course of inclusive education is relevant and necessitates its continuation.

\section{References}

Augustinienè, A., Burinskienè, R., Kajokienè, I. (2013). Priešmokyklinio amžiaus vaiku kalbos ugdymas taikant edukacines technologijas. Kaunas: Technologija.

Babinskienè, A. (2021). Ateities mokykla - ta, kurioje vertinamas vaiko individualumas. Prieiga internete: https://www. biciulyste.lt/lt/integracijos-keliu/2575-ateities-mokykla-ta-kurioje-vertinamas-vaiko-individualumas?fbclid=IwAR 15xfjPk7VuuUWaDFV2bH6xnZ_9JgUcFJWu-jrlUB7uUIdjKeS6rCW7_9M [žiūrèta 2021-03-24].

Baravykaitè-Dagienè, A., Gekienè, R., Burvyte, S. ir kt. (2014). Pasakos vaiko gyvenime: vaiku pasakos vaikams. Metodinè priemonè. Vilnius: Firidas. 
Beinorienè, R., Gražienè, V. (2016). Nuostabusis ženklu ir prasmių pasaulis. Patarimai priešmokyklinio ugdymo pedagogams. Vilnius: Ugdymo plètotès centras.

Berger, P. L., Luckmann, T. (1999). Socialinis tikrovés konstravimas. Vilnius: Pradai.

Bitinas, B. (2013). Rinktiniai edukologiniai raštai, T. 2: Edukologinis tyrimas: sistema ir procesas ugdymo tyrimu idejos ir problemos. Vilnius: Edukologija.

Bos, A. F., Braeckel, K., Hitzert, M. (2013). Development of fine motor skills in preterm infants. Prieiga internete: https://onlinelibrary.wiley.com/doi/full/10.1111/dmcn.12297 [žiūrèta 2021-03-24].

Boyd, D., Bee, H. (2011). Augantis vaikas. Vilnius: ŠMM, UPC.

Braslauskienė, R., Norvilienė, A., Šmitienè, G. ir kt. (2018). Patirtinis ugdymas(-is) vaikystëje: šiuolaikinès medijos ir informaciniu komunikaciniu technologiju galimybès. Klaipėdos universiteto leidykla.

Bražienè, N., Šalkuvienė, O. (2020). Taisyk žodžiui ir skaičiui kelią: idèjos ikimokyklinio ir priešmokyklinio amžiaus vaiku kalbai ir matematiniams gebèjimams ugdyti(s). Metodinė priemonè. Šiauliai: ŠU.

Brinkman, S. (2018). The Interview. The SAGE Handbook of Qualitative Research. Fifth Edition. London: SAGE.

Brodin, J., Renblad, K. (2018). Improvement of preschool children's speech and language skills. Prieiga internete: https://www.tandfonline.com/doi/full/10.1080/03004430.2018.1564917 [žiūrèta 2021-03-21].

Bunce, P. (2020). The Importance of Fine Motor Skill Development. Prieiga internete: https://penfieldbuildingblocks. org/developmental-milestones/importance-fine-motor-skill-development/ [žiūrèta 2021-03-21].

Burškaitienè, R. (2018). Yga Ga pedagogo knyga. Vilnius: Šviesa.

Celik, B. (2020). A Study on the Factors Affecting Reading and Reading Habits of Preschool Children. International Journal of English Linguistics, Vol. 10, No. 1, p. 101-114.

Cohen, L., Manion, L., Morrison, K. (2007). Research Methods in Education. London: Routledge.

Creswell, J. (2013). Qualitative Inquiry and Research Design: Choosing among Five Approaches. Los Angeles: SAGE.

Gaižauskaite, I., Valavičienè, N. (2016). Socialiniu tyrimu metodai: kokybinis interviu. Vadovèlis. Vilnius: RC.

Hesse-Biber, Sh. N., Leavy, P. (2011). The Practice of Qualitative research. Sage Publicaation.

Hille, K., Evanschitzky, P., Bauer, A. (2015). 3-6 metu vaiko raida. Psichologijos pagrindai ikimokyklinio amžiaus vaiku ugdytojams. Vilnius: Tyto Alba.

Hutton, J. S., Phelan, K., Horowitz-Kraus, T. ir kt. (2017). Shared Reading Quality and Brain Activation during Story Listening in Preschool-Age Children. Prieiga internete: <https:/www.sciencedirect.com/science/article/abs/pii/ S0022347617310971> [žiūrèta 2021-03-20].

Ikimokyklinio ugdymo pasiekimu aprašas. (2014). Prieiga internete: https://www.smm.lt/uploads/documents/tevams ugdymo_planai/knyga\%20-\%20rekomendacijos.pdf [žiūrèta 2021-04-18].

Jakavonytė-Staškuvienė, D. (2017). Kalbų didaktikos integravimas kitų dalykų pamokose pradinėse klasėse (Šveicarijos patirtis). Mokslu gristo švietimo link. Vilnius: Lietuvos edukologijos universitetas, p. 266-309.

Jakavonytė-Staškuvienè, D., Vozbinaitè, K. (2016). Priešmokyklinès grupès vaiku skaitymo gebėjimu ugdymas. Prieiga internete: <https://etalpykla.lituanistikadb.lt/object/LT-LDB-0001:J.04 2016 1504092864074 /J.04 2016 1504092864074.pdf> [žiūrèta 202-03-15].

Jankauskienè, I., Rinkevičiūtè, U. (2017). Priešmokyklinio amžiaus vaiku literatūrinio ugdymosi galimybės. Prieiga internete: <http://dspace.kauko.lt/bitstream/handle/1/1121/Ikimokyklinio\%20ir\%20priesmokyklinio\%20 ugdymo\%20Pedagogu\%20rengimo\%20problema_13.pdf?sequence=1> [žiūrèta 2021-03-17].

JT Neigaliujų teisių konvencija. (2006). Prieiga internete: <https://e-seimas.lrs.lt/portal/legalAct/lt/TAD/TAIS.335882> [žiūrèta 2021-03-24].

Jūrevičiūtè, K. (2013). Mama, tèti, padèk man kalbèti. Vaiko kalbos ugdymas nuo kūdikystès. Vilnius: Išmintis.

Karvelienè, R. (2019). Studentu, patekusiu i negalios situaciją, igalinimas dalyvauti aukštojo mokslo tarptautinėse veiklose. Daktaro disertacija. Šiauliai.

Kauffman, J. M., Anastasion, D., Badar, J. ir kt. (2016). Inclusive Education Moving Forward. General and Special Education Inclusion in an Age of Change: Roles of Professionals Involved, Vol. 32, p. 153-178.

Kyriazopoulou, M., Bartolo, P., Björck-Åkesson, E. (2017). Ankstyvojo amžiaus vaiku ịtraukusis ugdymas: naujos įžvalgos ir ịrankiai. Prieiga internete: <european-agency.org/sites/default/files/iece-summary-lt_0.pdf?fbclid=IwAR3x_myiOgKkQLRw-Q2chGiiSNIu-a_J4mQJj4bUdKfwF67p5v3EcOvsJ_M> [žiūrèta 2021-03-24].

Lietuvos pažangos strategija „Lietuva 2030“. (2012). Prieiga internete: <https://e-seimas.lrs.lt/portal/legalAct/lt/TAD/ TAIS.425517> [žiūrèta 2021-03-10].

Lietuvos Respublikos Švietimo įstatymo pakeitimo įstatymas. (2011). Prieiga internete: <https://e-seimas.lrs.lt/portal/ legalAct/lt/TAD/TAIS.395105> [žiūrèta 2021-03-17].

Locher, F., Pfost, M. (2019). The relation between time spent reading and reading comprehension throughout the life course. Prieiga internete: <https://onlinelibrary.wiley.com/doi/full/10.1111/1467-9817.12289> [žiūrèta 2021-03-21].

Monkevičienè, O. (2018). Pedagogams ir tévams apie penkerių-šěseriu metu vaikų raidos ir ugdymo ypatumus. Vilnius: ŠMM. 
Razgevičienė, L. (2016). Žaismès principas ugdant kalba ikimokykliniame ir priešmokykliniame amžiuje. Prieiga internete: http://ugdymocentrasvarpelis.lt/wp-content/uploads/2014/07/\%C5\%BDaism\%C4\%97s-principas-ugdantkalb\%C4\%85-ikimokykliniame-ir-prie\%C5\%A1mokykl_iniame-am\%C5\%BEiuje.pdf [žiūrèta 2021-03-24].

Rupšienè, L. (2007). Kokybinio tyrimo duomenu rinkimo metodologija. Klaipėda: Klaipėdos universiteto leidykla.

Salamankos deklaracija. (1994). Prieiga internete: < https://en.unesco.org/themes/education/> [žiūrèta 2021-03-20].

Savickytè, K. (2018). Kuriame pasaka su aktore Kristina Savickyte. Vilnius: Alma littera.

Schady, N. (2011). Parent's education, mothers'vocabulary, and cognitive development in early childhood: Longitudinal evidence from Ecuador. Prieiga internete: < https://www.ncbi.nlm.nih.gov/pmc/articles/PMC3222428/> [žiūrėta 2021-03-10].

Suggate, S., Pufke, E., Stoeger, H. (2016). Do fine motor skills contribute to early reading development? Prieiga internete: <https://onlinelibrary.wiley.com/doi/abs/10.1111/1467-9817.12081> [žiūrèta 2021-03-24].

Teixidor, E. (2014). Skaitymas ir gyvenimas. Vilnius: Lietuvos nacionalinė Martyno Mažvydo biblioteka.

Turauskienè, E. (2019). Pedagogo bendradarbiavimo su tėvais galimybės ugdant priešmokyklinio amžiaus vaikų komunikavimo kompetenciją darželyje: tèvų nuomonè. Gerovès visuomenès kūrimo iššūkiai Lietuvoje ir pasaulyje. Klaipeda: KU, p. 28-34.

Turauskienė, E., Braslauskienè, R. (2020). Priešmokyklinio ugdymo mokytojo bendradarbiavimo su tėvais galimybės ugdant vaikų komunikavimo kompetenciją darželyje: priešmokyklinio ugdymo mokytojų nuomonè. Scientific Research in Education, Vol. 3, p. 136-149. Vilnius: VU.

UNESCO. (2016). Prieiga internete: https://www.ilo.org/wcmsp5/groups/public/---ed_dialogue/---sector/documents/ normativeinstrument/wcms_493315.pdf [žiūrèta 2021-03-24].

Vaiko teisiu konvencija. (1989). Prieiga internete: https://e-seimas.lrs.lt/portal/legalAct/lt/TAD/TAIS.19848 [žiūrẻta 2021-03-24].

Valinskienè, E. (2012). Raidžiu mokymas Valdorfo mokykloje. Vilnius: BSPB.

Valstybiné švietimo 2013-2022 metu strategija. (2014). Prieiga internete: <https://www.sac.smm.lt/wp-content/uploads/2016/02/Valstybine-svietimo-strategija-2013-2020_svietstrat.pdf > [žiūrèta 2021-03-24].

Yustina, L. S. (2012). Children's language development in learning speaking and listening. Prieiga internete: $<\mathrm{https} / / /$ www.researchgate.net/publication/270483468_CHILDREN'S_LANGUAGE_DEVELOPMENT_IN_LEARNING_SPEAKING_AND_LISTENING> [žiūrèta 2021-03-21].

Zachovajevas, P., Katkienè, V., Šegždaitė G. ir kt. (2018). Diferencinio mokymo poveikis priešmokyklinio amžiaus vaikų rankų miklumui. Visuomenès sveikata, Nr. 6, p. 44-50.

Žičkevičienè, A., Bagdonas, A. (2020). Pasakų reikšmė ugdant kalbinius ịgūdžius ikimokykliniame amžiuje. Studijosverslas-visuomené: dabartis ir ateities ǰžvalgos. Klaipėda: KVK, p. 162-168.

Žydžiūnaite, V., Sabaliauskas, S. (2017). Kokybiniai tyrimai. Principai ir metodai. Vilnius: Vaga.

\title{
IKIMOKYKLINIO AMŽIAUS SPECIALIŲJŲUGDYMOSI POREIKIU巳 TURINČIU VAIKŲ KALBINIŲ GEBËJIMŲ U GDYMAS，VYKDANT İTRAUKŲJİ UGDYMĄ
}

\author{
Rasa Braslauskiené, ERIKa TurauskienĖ \\ Klaipèdos universitetas (Lietuva)
}

\section{Santrauka}

Šių dienų švietimo ir ugdymo diskursuose akcentuojama, kad kiekvienas vaikas yra unikali, aktyvi, besikeičianti individualybè, kuriai turi būti sudarytos galimybės augti ir ugdytis ten, kur geriausiai tenkinami jo poreikiai bei švietimo pagalbos reikmès (Kauffman, Anastasion, Badar ir kt., 2016; Babinskienė, 2021). Todèl pastaruoju metu specialiųų ugdymosi poreikių turintys vaikai dažnai įtraukiami i ịprastai besivystan- 
čių vaikų grupes. Tarptautiniuose ir Lietuvos strateginiuose dokumentuose (Vaiko teisių konvencija, 1989; Salamankos deklaracija, 1994; JT Dakaro pasaulio švietimo forumas, 2006; JT Neigaliujų teisių konvencija, 2006; Lietuvos pažangos strategija „Lietuva 2030“, 2012 ir kt.) akcentuojama švietimo sistemos pertvarka. Juose nusakoma būtinybe įgyvendinti ịtraukųjị ugdymą, taip užtikrinant galimybę kiekvienam vaikui dalyvauti ugdymo procese pagal jo gebejimus ir poreikius bei gauti savalaikę pagalbą. Ikimokyklinio ugdymo grupejje kalbinių gebejjimų ugdymas yra integrali grupės gyvenimo dalis. Kiekviena vaikų diena ugdymo įstaigoje susideda iš situacijų, kurios savaime ugdo vaikų kalbinius gebejimus. Vaikai, nepaisant jų lyties, funkcinių galimybių, socialinio, kultūrinio pagrindo, kiekvieną dieną gali natūraliai bendrauti žaisdami, per pusryčius, pietus, pavakarius ir kt. (Schady, 2011; Hille, Evanschitzhy, Bauer, 2015). Tačiau, be natūralių situacijų, kur ugdomi vaikų kalbiniai gebejjimai, taikomi ir ịvairūs ugdymo metodai, būdai, priemonès, kurias ikimokyklinio ugdymo mokytojai (IUM) pasirenka atsižvelgdami ị savo ugdytinių individualią patirtį, galias, raidos dėsningumus. Tad šiame straipsnyje keliamas probleminis klausimas: kokie yra specialiujų ugdymosi poreikių (SUP) turinčių ikimokyklinio amžiaus vaikų kalbinių gebëjimų ugdymo(si) ypatumai, vykdant įtraukujji ugdymą? Tyrimo objektas - ikimokyklinio ugdymo mokytojų nuomonès apie specialiujų ugdymo(si) poreikių turinčių ikimokyklinio amžiaus vaikų kalbinių gebėjimų ugdymo(si) ypatumus, vykdant įtraukųji ugdymą. Keliamas tyrimo tikslas - atskleisti ikimokyklinio amžiaus specialiųjų ugdymosi poreikių turinčių vaikų kalbinių gebėjimų ugdymosi ypatumus, vykdant ịtraukụji ugdymą. Siekiant atskleisti IUM nuomonę apie SUP turinčių ikimokyklinio amžiaus vaikų kalbinių gebejjimų ugdymo(si) ypatumus, vykdant ịtraukujji ugdymą, pasirinktas interviu metodas. Atliekant tyrimą rinkta, analizuota, sisteminta mokslinëje literatūroje ir dokumentuose pateikta informacija, atliktų mokslinių tyrimų duomenys ir rezultatai; pasirinkta tyrimo strategija, kuriamas tyrimo dizainas; sudaromas tyrimo instrumentas; vykdomas iš dalies struktūruotas interviu; analizuojami, apibendrinami duomenys, rengiama tyrimo ataskaita. Kokybiniam tyrimui pagrįsti remtasi interpretacine paradigma (Cohen, Manion, Morrison, 2007) ir konstruktyvistine prieiga (Berger, Luckamann, 1999). Jos pritaikytos siekiant pateikti interpretacinį, visumini, analizuojamos situacijos vaizdą, joje dalyvavusių asmenų ,išgyventą patirți“ ir iš situacijų analizės kylantị paaiškinimą. Atsižvelgiant ị darbo tikslą, tirti atrinkti individai, galintys suteikti prasmingos informacijos apie tiriamą dalyką. Šiuo atveju tai penki IUM, dirbantys ịtraukiojo ugdymo grupèje, turintys darbo su emocijų ir elgesio, sulètejusios raidos, dèmesio bei aktyvumo vaikais patirties. İtraukioji grupè - tai grupè, kurioje pripažįstama kiekvieno vaiko teise ị ugdymąsi kartu su bendraamžiais.

Atlikus kokybinị tyrimą nustatyta, kad kalbinių gebėjimų ugdymas, vykdant SUP turinčių vaikų ịtraukujj ugdymą, pedagogams yra kalbẻjimo, klausymo(si), rašymo ir skaitymo ugdymas, atsižvelgiant ị kiekvieno vaiko gebėjimus, poreikius, temperamentą, charakterị. Interviu surinkti duomenys atskleidè kalbinio ugdymo ypatumus. IUM nuomone, ịtraukiojo ugdymo vaikų darželyje procese SUP vaikų sakytinès ir rašytinės kalbos gebėjimai ugdosi savaime, vykdant kasdienę veiklą. Tačiau ịtraukujį SUP turinčių vaikų ugdymą vykdantys IUM, siekdami ugdyti sakytinės kalbos gebejjimus, skatina vaikus žaisti įvairius žaidimus; inicijuoja pokalbius; taiko dialoginio skaitymo metodą; inicijuoja artikuliacinę mankštą; skatina tyrinèti informacinių technologijų galimybes; supažindina vaikus su kalbos etiketo taisyklėmis ir kt. Paaiškèjo, kad ugdydami vaikų rašytinès kalbos gebejimus, IUM ragina juos kopijuoti, rašinèti raides; moko taisyklingai naudotis piešimo, rašymo priemonėmis, žirklėmis; inicijuoja kūrybinę veiklą; skiria vaikams asmeninị dėmesį suteikdami reikiamą pagalbą ir kt.

Atlikus tyrimą nustatyta, kad pedagogai, vykdantys ịtraukujji ugdymą, susiduria su šiais SUP turinčių vaikų sunkumais: sunkiai sukaupia dèmesị; negeba laikytis grupeje numatytos tvarkos. Siekdami įveikti sunkumus informantai bendrauja, bendradarbiauja su ugdytinių tèvais. Glaudus bendradarbiavimas su tèvais padeda nustatyti vaikams aiškias ribas; suartina tèvus su vaikais, pedagogais, užtikrina ugdymo(si) tęstinumą bei kokybę. Pedagogų nuomone, siekiant tobulinti SUP turinčių vaikų kalbinių gebejjimų ugdymą, vykdant ịtraukụji ugdymą, ateityje reikètų aktyviau įtraukti specialistus, tẻvus, mažinti vaikų skaičių ịtraukiojo ugdymo grupėse; išbandyti ugdymą judant; taikyti STE(A)M metodikas; perimti užsienio šalių gerają patirti ir kt.

Apibendrinant kokybinio tyrimo radinius svarbu pažymėti tyrimo apribojimus. Kokybinių tyrimų ribotumas sietinas su neišvengiamu šių tyrimų subjektyvumu. Nors planuojant ir atliekant ši tyrimą laikytasi tokio 
pobūdžio tyrimams būtinų reikalavimų, tyrimo rezultatų generalizavimą ir jų pritaikymo galimybes riboja iš dalies mažas tyrimo dalyvių skaičius. Kokybinių tyrimų radiniai yra unikalūs ir būdingi tik šiame tyrime dalyvaujantiems asmenims. Šio tyrimo išvados leidžia teigti, kad SUP turinčių ikimokyklinio amžiaus vaiku kalbinių gebẻjimų ugdymo(si) tyrimai, vykdant ịtraukųji ugdymą, yra aktualūs, tad juos reikètų tęsti.

PAGRINDINIAI ŽODŽIAI: specialieji ugdymosi poreikiai, kalbiniai gebejjimai, ịtraukusis ugdymas.

JEL KLASIFIKACIJA: I21, I25.

Received: 2021-03-06

Revised: 2021-04-28

Accepted: 2021-05-04 